\title{
The Revolution of the Tax System based on Flat Tax
}

\author{
By Rui M. Zeferino Ferreira* \\ Fábio Veiga ${ }^{\dagger}$
}

\begin{abstract}
Based on the idea that the tax systems coexist with the incurable and complex problem of choice, compatibility and preferably between efficiency and equity, we intend to conclude that the legislator of the Western countries is opting for equity in detriment of efficiency in the tax system. Consequently, it is important to realise that a system of marginal growing taxes has been used, based on a false idea of tax equality and fair distribution of the responsibilities. In the absence of an optimal tax system in an imperfect world, we intend to demonstrate that the Flax Tax combined with the theories of the supply-side economics, and with the reduction of the State's presence in society and the economy, represents a fairer and more equitable redistribution of income and more efficient from an economic point of view, in order to get a number of positive aspects on economic growth.
\end{abstract}

Keywords: Tax System, Flat Tax, Supply-Side Economics.

\section{Introduction}

The understanding of a tax system based on flat tax involves the integrated study of taxation, but also of public finances and political economy. In fact, most of the studies and comments to the subject have proceeded as if each of these areas was independent, not addressing the issue in order to integrate all its aspects ${ }^{1}$.

The modern State presents itself, from the point of view of financing, as a true fiscal $s^{2}{ }^{2}$, but also as a welfare state, in which these two realities blur together and are inseparable, not existing the second without the first. In fact, the existence of state depends on the existence of a fiscal state ${ }^{3}$. Thus, before a state shaped this way, taxes constitute a price to pay for the society we have, being at the confluence of interests of the State and citizens alike.

\footnotetext{
${ }^{*}$ Researcher in Law PhD Program, Universidade de Santiago de Compostela, Galicia, Spain.

${ }^{\dagger}$ Researcher, Universidade de Vigo, Galicia, Spain and Capes Foundation, Brazil.

${ }^{1}$ desde logo, o estudo relacionado e integrado do sistema fiscal com a estrutura económicosocial» [When speaking of tax structure, he has in mind, therefore, the related and integrated study of tax system with the socio-economic structure].

${ }^{2}$ Nabais (2015b).

${ }^{3}$ According to Catarino \& Guimarães (2012), there will be no state tax, which constitutes the essential element for the continuation of policies.
} 
If it was possible to reach a great point we would be faced with an ideal tax system, in which there would be a good $\operatorname{tax}^{4}$. The consideration of an ideal tax system ${ }^{5}$ has fallen into the mistake of being influenced by ideological and political factors, which removes objectivity and makes tax systems insecure and volatile to the exchange of political parties in governance. Although utopian, Stiglitz considers some characteristics for the tax systems as desirable: «a eficiência, envolvendo a necessidade de não introduzir distorções e, se possível, contribuir para a eficiência da economia, a simplicidade administrativa, a flexibilidade, permitindo a adequação a diferentes circunstâncias, a responsabilização política, envolvendo a transparência e a justiça com o tratamento igual daqueles que estão em situações iguais $e$ exigindo mais aos que podem pagar mais» ${ }^{6}$.

The tax systems coexist with the incurable and complex problem of choice, preference and compatibility between efficiency and equity ${ }^{7}$ or, in the words of Musgrave ${ }^{8}$ between affectation, stability and distribution. In this equation, Western Europe has opted for equity at the expense of efficiency of the tax system through a system of marginal tax rates based on an idea of equality and fair redistribution of the tax burden.

\section{The Current Context, Globalization and the Change of Paradigm}

With the phenomenon of globalization, new challenges have emerged, which should have (already) forced the mutation of the tax system. This phenomenon, from the point of view of taxation, brought not only competition between economic operators, but also between the various tax systems by reducing the tax burden. In addition, tax competition promoted the growth of tax avoidance and abusive tax planning through the proliferation of countries, areas and regions of low or zero taxation. The response to these problems was an excessive and incomprehensible set of standards that made the tax systems complicated, overly costly and difficult to understand for the taxpayers.

For example, in the Portuguese case we can notice some peculiarities, such as the tendency of growth of the tax burden as opposed to options that occurred in the same timeline in other countries, and by a tax reform, in the late 80s, against the cycle that was happening in Europe.

\footnotetext{
${ }^{4}$ The first rigorously theorizing about this concept was developed by Adam Smith. See Ferreira (2004) 191; Franco (1995) 168.

${ }^{5}$ In Frrreira 2004) 191, attention is drawn to the fact that the notions of real tax system and ideal tax system are different.

${ }^{6}$ Stiglitz (2000) 456 also quoted in Ferreira (2004) 192 fn. 192) [the efficiency, involving the need to not introduce distortions and, if possible, contributing to the efficiency of the economy, administrative simplicity, flexibility, allowing the adaptation for different circumstances, political responsibility, involving transparency and justice with the equal treatment of those who are in the same situations and demanding more to those who can pay more].

${ }^{7}$ See authors as Musgrave, Adam Smith, Stuart Mill, David Hume e Keynes, on the debate of justification and size of state intervention.

${ }^{8}$ Musgrave \& Musgrave (1989).
} 
In fact, the Portuguese tax system is heavy, with significant reliance on indirect tax, which taxes transactions made abroad and which bills itself as a redistributive tax system. The increasing development of the welfare state has promoted and increased fiscal pressure, putting into question the maintenance of the idea of social solidarity, which has been at the basis of creation and justification of taxes as a price to pay for an organised society, but which is reaching the saturation point. Furthermore, today taxpayers demand a simpler, more accessible, less costly, and understandable tax system, one which encourages economic activity. In addition, the current system is quite illusory and, although the constitutional law continues to affirm the progressiveness, the truth is that more and more types of income are subject to taxation according to a constant marginal rate, leaving the growing marginal rates essentially for the employment income.

It is in this context that the flat tax appears, as a new revolution for the tax systems, with a wide range of advantages and fulfilling the elements indicated to an ideal tax system. The central idea which has presided over reforms of tax systems throughout Europe is the simplification, based on this phenomenon of flat tax revolution ${ }^{9}$.. This doctrine, which was developed in the United States of America, has been adopted in a non-uniform way in the states of Central and Eastern Europe and discussed all over the European continent. Its application in those countries has obtained success and, despite the existence of differences in implementation in several countries, it is based on a constant marginal tax rate, simple and reduced, but, still, without being the pure flat tax theorised by professors Robert Hall and Alvin Rabushka ${ }^{10}$.

In Portugal, some authors, such as José Casalta Nabais ${ }^{11}$ has questioned whether such a system could be implemented, but the approach has been limited to consider that the country does not have economic and financial conditions to enter this reform movement because, according to this author, it would lead to the bankruptcy of the state, or at least of the welfare state. Another argument for refusal has been the constitutional requirement of progressive taxation of personal income, however, for José Neves Cruz «apesar de a taxa marginal ser constante, este imposto [linear (flat tax)] é progressivo, pois as taxas médias de imposto são crescentes» ${ }^{12}$. In fact, there is a part of negative tax and a minimum income tax, which makes the average to grow with the level of income. Thus, such arguments cannot proceed, because on the one hand, the reform would be financially neutral, without additional financial burden and, on the other, the flat tax is progressive in itself.

In reality, some studies ${ }^{13}$ support that the implementation of the flat tax entails some problems on redistribution, fairness and reducing revenue to Western European countries. However, the referenced study states that the «flat

\footnotetext{
${ }^{9}$ Forbes (2005).

${ }^{10}$ Hall \& Rabushka (1995).

${ }^{11}$ Nabais (2015b).

12 Cruz (2008) 157. Trans. [although the marginal rate is constant, this tax is progressive because the tax rates are soaring].

${ }^{13}$ Paulus et al (2009) and Peichl (2006). See also about Spain, (Cabré (2000)); about Serbia (Randjelovic \& Zarkovic-Rakic (2010)); and about Germany (Peichl, (2006)).
} 
tax implementation seems more favorable in the southern European countries (Portugal, Greece and Spain)» ${ }^{14}$. In the face of positive effects on efficiency and economic growth of these countries, it is understood that a certain level of inequality in terms of equity and redistribution can be acceptable. Even at this point, the cited study concluded that «for some Mediterranean countries the flat tax can increase both equity and efficiency» ${ }^{15}$.

\section{The Supply-Side Economics and the Flat Tax}

\section{The Supply-side Economics}

The solution is the compatibility of the analytical results of the Laffer curve $^{16}$ with the vitality of laws governing the economy, as they defend the theories of supply-side economics ${ }^{17}$. These theories sustain the existence of lower marginal rates and greater simplicity of the tax system by implementing a flat tax. These theories, on the one hand, confirm that the degree of elasticity of supply factors was underestimated and, on the other hand, contest the Keynesian-inspired policies, which, starting from a definition of full employment and aggregate demand, justified the intervention of the state, but that have just been artificially sustaining the economic activity and employment, which sooner or later would have to end up in runaway inflation and fiscal uncontrol.

In fact, tax cuts have been neglected as an instrument of adjustment and economic recovery, in favour of the multiplier effect of public spending, whose effects have been overrated. But even paying more taxes, an incidence according to a constant marginal rate on all income earned by a taxpayer, without double or triple taxation replicas, depending on the applications given to them, will undoubtedly be fairer ${ }^{18}$. The flat tax, pulling out from the income of any taxpayer the same percentage, presents itself as a more equitable

\footnotetext{
${ }^{14}$ Peichl \& Paulus (2009) 31.

${ }^{15}$ Peichl \& Paulus (2009) 31

${ }^{16}$ The Laffer curve was developed by Arthur Laffer. It is a hypothetical representation of the relationship between the revenue from taxation and all possible rates of taxation. This curve is used to illustrate the concept of elasticity of the different tax rates, which changes according to the change in the rate. What the author advocates is that the potential outcome of the curve, caused by the increase of the tax rate from a certain level of tax burden will be counterproductive with the growth of tax revenue, by having the opposite effect and undesirable reduction of tax revenue. This result represents an estimate, being controversial in various countries.

${ }^{17}$ The so-called theories of supply-side economics represent the macroeconomic school of the economy of supply, whose thought argues that economic growth will be more effective by reducing the barriers to the production or supply of goods. This thought advocates the reduction of taxes on income from labour and capital, with greater simplicity and flexibility. According to the economy of supply, consumers will benefit from a greater supply of goods and services at lower prices.

${ }^{18}$ Araújo (2004); Friedman (2002); Mises (2012).
} 
solution. In fact, one should not forget the discouraging result that the current marginal rates, for being excessive, cause in the performance of economic agents. The high marginal rates are decreasing the growing desire to work more than the minimum required with effects on the stagnation of production and productivity. Indeed, if the tax burden increases, economic operators will reduce the supply of the productive services that they hold, but if the fiscal pressure decreases the inverse phenomenon occurs with the increase of supply.

Efficient economic performance cannot be obtained with policies that operate on demand, through the budgetary and monetary instruments that do not promote production investments. So, without incentives to investment the capital formation will tend to stagnate. In addition, high tax rates discourage work, with the consequent reduction of effort, productivity and amount of supply.

Conversely, by increasing the aggregate supply through the rise of the curve of production possibilities, the growth of the use of productive and product factors is achieved with the reduction of inflation. Therefore, for more than 30 years, the misconception that increased public spending could lead to further growth of product and demand prevailed. At the end of this period of time, we should, on the contrary, conclude that there is a very close link between inflation and the increase in the level of expenditure arising from the continuous accumulation of budget deficits. This phenomenon caused a negative impact on the tax system, by means of tax increase on the supply factors ${ }^{19}$.

The loss of momentum and the decline of growth is a direct consequence of the Keynesian-inspired ${ }^{20}{ }_{-}^{21}$ interventionist State, with major social programs that penalise labour and savings by increasing taxes, encouraging fraud, the black economy, abusive tax planning, the recourse to countries and regions of low or zero taxation and multiplying the regulations and legislative restrictions.

The inversion of the current fiscal state involves a break with the ideology of the last decades, limiting excessive state involvement in the economy and promoting the simultaneous reduction of public spending and taxes. The reasons arise from the fact that the budget deficit is in itself a consequence of the fiscal pressure that penalises the offer. In addition, taxes cannot stimulate the job offer, savings and investment effectively if they are not accompanied by the progressive reduction of public spending. Finally, the simple reduction of public expenditure is insufficient if the tax system is not reformed, because

\footnotetext{
19 The thought expressed is supported both by the Chicago School, based at the thought of Milton Friedman and George J. Stigler, and the Neoclassical School, which bases its reasoning in the thought of Adam Smith. Both schools reject the foundations of the Keynesian thinking, supporting theories of supply-side economics, see Friedman \& Friedman (2012). Joseph Stiglitz, for example, argues the opposite.

${ }^{20}$ From 2008 onwards, there was a new stimulus around the Keynesian thinking, in which policy makers began to announce economic stimulus packages, in order to exclude the possibility of a global depression. This consensus did not last long in the face of theories that advocate the reduction of taxes as a boost to economic development.

${ }^{21}$ See among others Friedman (2002); Friedman \& Friedman (2012); Mises, (2012).
} 
only then the gains resulting from the release of public funds to the private sector will be effective.

The Flat Tax ${ }^{22}$, a New Tax Agreement

From the beginning of the years 90, several countries in Eastern Europe and Central Europe ${ }^{23}$, as Estonia (1994), Lithuania (1994), Latvia (1995), Russia $(2001)^{24}$, Serbia ${ }^{25}$, Ukraine, Slovakia ${ }^{26}$ (all in 2003) and Romania ${ }^{27}$ (2005) have carried out reforms in their tax systems by implementing a simple, single tax rate and linear. The flat tax was a proposal that gained notoriety from the academic work developed by Alvin Rabushka and Robert Hall, although previously Friedrich Hayek ${ }^{28}$ has written about a flat rate.

The flat $\operatorname{tax}^{29}$ is a simplified tax system with a linear tax rate, applied on a broad tax base, without rebates, deductions, special arrangements and exceptions (save the exemption resulting from the application of negative tax), through a constant, relatively low ${ }^{30}$, tax marginal rate This system is in contrast to the traditional tax systems operating in most countries, in which there are different marginal rates of tax for certain levels and types of income. For example, the Portuguese case simply analyses article 68 of the code of the personal income tax, the wide range of withholding tax rates and rules relating to the inclusion of income. However, there is today a growing concern in all countries with traditional tax systems about the high level of taxation, either in companies or individuals, and the unfavourable consequences of fiscal competition at international level.

This tax system of flat tax, in addition to require that all taxpayers are taxed according to a constant marginal tax rate, has other features ${ }^{31}$ that are usually present in most flat tax proposals, in particular, the marginal tax rates, the elimination of tax deductions, exemptions and benefits, with a view to the already mentioned simplification. This objective implies the end of most

\footnotetext{
${ }^{22}$ See about the subject, among others, Browning \& Browning (1985) 629-649; Caterbery, Cook, \& Schmitt (1985) 521-536; Cook (1985) 477-480; Egger (1985) 537-542; Gwartney \& Long (1985) 407-430; Hall \& Rabushka (1985) 465-476; Hall \& Rabushka (1995); Lee (1985) 433-436; Minarik (1985) 437-447; Peterson (1985) 651-656; Stroup (1985) 449-453).

${ }^{23}$ The rates adopted in each of these countries range from 13\% (Russia) to 33\% (Lithuania).

${ }^{24}$ See about the implementation of the flat tax in Russia, the international monetary fund's report - Keen, Ivanova, \& Klemm (2005).

${ }^{25}$ See about the implementation of the flat tax in Serbia - Randjelovic \& Zarkovic-Rakic (2010).

${ }^{26}$ See about the implementation of the flat tax in Slovakia, the report from the Organization for Economic Cooperation and Development and the International Monetary Fund's report - Brook \& Leibfritz (2005); Moore (2005).

${ }^{27}$ See about the implementation of the flat tax in Romania - Voinea \& Mihaescu (2009).

28 This author develops in several of his works, though in a sparse way, the issue of implementing a flat tax - see Hayek (1992) 2013.

${ }_{29}$ See in more detail and development, the report of the international monetary fund Keen, Kim, \& Varsano (2006), about the principles and the evidence of the flat tax.

${ }^{30}$ See Cruz (2008) 157).

${ }^{31}$ Teather (2005).
} 
existing specific deductions in the tax system. However, not all income is subject to tax, because the flat tax envisages the existence of an exemption to certain income levels, such as taxpayers with lower resources. Thus, it is assumed that the flat tax increases the personal benefit to ensure that all lowincome taxpayers are not affected by the application of a constant marginal rate, which in some cases will be higher than the marginal rate currently applicable. Hence, the tax collected increases according to the growth of the income of the taxpayer and not by the growth of the marginal tax rate, which increases according to levels of income.

The new fiscal agreement based on flat tax should start from the assumption that it is preferable to have income redistributed without disproportionate cost to each taxpayer, based on the effort of each one. That is, what each one produced and the contribution each one had for the product. Under this new contract, the current problem of credibility of the fiscal system should be solved through the establishment of compensatory measures for taxpayers who pay taxes, and there is a moral and political responsibility to combat wastage in spending and free up the economy from supply ties that inhibit the creation of wealth.

Therefore, one should adopt the flat tax, abandoning the use of rising marginal rates, which impend over the ones who produce more. In turn, although having a redistributive function that is not confined to transfers of tax revenues for the benefit of taxpayers subject to the "zone" of negative tax income, the state must turn back to its original function of financing the costs of public goods, those whose consumption does not cause the decrease of others, for which there are no incentives to its offer, and those that contain positive externalities.

The proponents of the flat tax argue that it is the dynamics of supply and the growth of the gross domestic product that should contribute to the growth of tax revenue ${ }^{32}$, because the more the gross domestic product grows, the higher the taxable profit and, consequently, the budget.

The countries that have adopted these systems intend to, especially, benefit from tax competitiveness that underlies at reduced rates, but also for reasons of fairness and justice, because the tax system will only be fair if it is equitable and simple, purged of all its declarative complexities, and conducive to a harmonious economic growth ${ }^{33}$. The model of the flat tax does not require increasing marginal rates to be, in itself, a truly progressive system, once the progressivity is achieved by the prediction of a personal and family reduction, applied equally to all levels of income. Thus, the effective rate of taxation is always less than the marginal rate that is embodied in such a system.

We can sum up the advantages of the flat tax to simplification of the tax system, both its management by the state and its understanding by taxpayers, by increasing the effect of compliance and of conformity on the part of the

\footnotetext{
${ }^{32}$ In this sense, see the theory developed by professors Robert Hall and Alvin Rabushka - Hall \& Rabushka (1995).

${ }^{33}$ According to Fernando Araújo and João Ricardo Catarino - see Araújo (2004) 925-931; Catarino (2008) 590-605.
} 
latter, which by understanding the functioning of the tax system will more easily comply with their tax obligations. Being simpler, tax fraud and evasion will be more difficult due to the lack of compensation consistent with the risk involved in such activity, as well as its management by the state will be more cost-effective. From an economic point of view, it constitutes an incentive for economic activity, attracting domestic and foreign investments and puts an end to the distortions of economic double taxation of savings and investment. Finally, as an ethical issue, it makes the tax system more transparent. This way, it is truly suitable for the conclusion of João Ricardo Catarino when he says that «A taxa única não é pois inimiga da justiça fiscal. Nem da progressividade do imposto» ${ }^{34}$.

The flat tax system entails that the most varied economic options of the taxpayer are taxed in exactly the same way, avoiding tax planning to find ways to more favourable taxation.

The tax rate will be, on average, lower, which can bring to a loss of tax revenue, but that will be compensated by the extended tax base and the abolition of benefits, exemptions and special taxation schemes. In addition, the loss of tax revenue will be lower due to reduced tax evasion in face of the economic disincentive that tax planning becomes into. Also, the reduction of tax revenue does not result in an equal increase in the financing needs of the public sector ${ }^{35}$. For example, a greater incentive to work with employment effects will reduce the needs for payment of subsidies. In fact, the reduction in the tax rate will, conversely, make the economy grow more quickly, resulting in more wealth to taxpayers and, this way, in a higher level of tax revenues ${ }^{36}$.

The flat tax also promotes the reduction of the costs of compliance and enforcement, i.e., it has very positive effects on the economy and, this way, on the economic and political stability. This means that its impact will be greater than the cut in tax rates ${ }^{37}$. aumentaram com as reformas o montante total de imposto liquidado e pago

The reforms carried out in the various countries that have adopted this tax system showed that the reduction of tax rates on taxpayers with greater financial capability made it possible to quickly obtain greater revenue from these taxpayers than the one which was previously charged. That is, the wealthiest taxpayers, according to the system of taxation by increasing marginal rates, increased the total amount of output and paid $\operatorname{tax}^{38}$ with the

\footnotetext{
${ }^{34}$ Catarino (2008) 595. Trans. [the single rate is neither enemy of fair taxation nor of the progressivity of the tax].

35 Teather (2005).

${ }^{36}$ Andrei Grecu observes that «the 1980s: President Reagan reduced the top tax rate even more drastically, from 70 percent in 1980 to 28 percent by 1988. As a result, during the sevenyear Reagan boom, economic growth averaged almost 4 percent per year. Total tax revenues also expanded impressively by 99.4 percent during the 1980s» - v. (2004).

${ }^{37}$ In this respect, the studies of Andrei Grecu, Liviu Voinea, Richard Teather and Stuart Adam on the application of the flat tax should be noted in more detail - see Adam \& Browne (2006); Grecu (2004); Teather (2005); Voinea \& Mihaescu (2009).

${ }^{38}$ After the reforms of the ' 80 s, the United States of America taxpayers with greater financial strength that paid $35.3 \%$ of the total tax revenues began to pay the equivalent of $38.9 \%$ (1984).
} 
reforms. It has as also the effect of attracting wealthy contributors from other countries, individually or as administrators of companies, which will bring economic activity (expenses and business) for the country, as well as creating jobs, generating new tax revenues ${ }^{39}$..

The flat tax must integrate harmoniously the taxation of individuals and the collective people, whose purpose goes through the integration of all taxation on individuals, despite the theory built by Professors Robert Hall and Alvin Rabushka does go in this direction, where there is a differential tabulation for each taxable commodity. This system should tax businesses with the same tax rate, allowing the removal of the current potential for double taxation of dividends. This way, one of the main focuses of tax evasion would be eliminated, which derives from the different tax treatment among corporate bodies and individuals, ensuring that a particular income is taxed only once and in accordance with a constant marginal tax rate ${ }^{40}$.

In fact, behind the flat tax is a tax based on consumed income ${ }^{41}$, whose part that is considered as an investment should be removed from the taxable base and included only when it generates a consumed income. The essential idea is to promote and encourage economic growth, stimulate work and capital formation, through savings and business activity.

In the business sector, this system protects the non-taxation of business activity, but rather the income earned by entrepreneurs. The referred American authors defend that income obtained by the companies should be taxed there, and should not be subject to taxation in the declarations of its beneficiaries, when there is distribution.

The doctrine repeatedly points to the problem of rich taxpayers being the ones who most benefit from the flat tax, but certainly will not be so. After all, some of the reductions are targeted to lower-income holders. Indeed, everyone wins with the personal benefit, which would mean that many will be exempted from taxes ${ }^{42}$.. Thus, low-income taxpayers will be proportionally benefit more than wealthier taxpayers. Also, what helps more these contributors is a growing economy, allowing better paid jobs. The flat tax will make it possible to exclude the poorest taxpayers from paying taxes on personal income, removing any fiscal discouragement of job search, as well as the barriers to seek employment without the costs and distortions of the current benefits and tax exemptions.

The reduction in the marginal tax rate will make these wealthier taxpayers end up paying more taxes as a result of the reduction of tax evasion. This incentive will allow the creation of new jobs, avoiding the current system of disincentives to the creation of new enterprises and the expansion of the existing ones, and will recognise effort and risk-taking.

\footnotetext{
${ }^{39}$ Teather (2005).

40 See Catarino (2008); Cruz (2008); Teixeira\ (2010) about the reasons for and against the integration of the tax systems of natural and legal persons in one.

${ }^{41}$ Calarino (2008) 595-596.

${ }^{42}$ Grecu (2004); Teather (2005).
} 
The flat tax, unlike the current tax system, takes into account the world economy and tax competition between states, which will improve the international competitiveness and attract foreign investment, as was successfully done in Ireland ${ }^{43}$ and in many countries of Central Europe. In short, it is not intended to make the rich richer to the detriment of the poorest. In fact, the reduced marginal tax rates stimulate the investment, which make businesses more productive, create jobs and lift people out of poverty.

As mentioned above, this new fiscal agreement presupposes a consideration of the state's intervention in the economy and the consequent reduction of its duties. Furthermore, it will continue to be necessary to discuss in depth if the equality between citizens should be a goal to be achieved at all costs and if there is basis to achieve this equality through taxes ${ }^{44}$.

\section{Conclusions}

The problem of economic growth has various causes, but we focus our attention on the uncompetitive tax system, one which is also labour, productivity, savings and investment discouraging.

In fact, it is the same opinion of Georges Bragues, that over the last 30 years, «na tentativa de avançar o projeto social-democrata ou, como é chamado em Portugal, o Estado Social, o foco tem sido o de construir um aparato estatal que assegure os direitos positivos» ${ }^{45}$. However, such an option for social intervention was made at the expense of a discouraging level of taxes and high budget deficits. In this sense, an error has been made in emphasizing intervention as a way to bring the prosperity. As he defended by the Austrian School (Ludwig von Mises), socialist interventionism «is a kind of acid that will stock eroding capital of a company» ${ }^{46}$..

The welfare state must be supported by taxes that are increasingly scarce to take all financing needs, whose increases have reduced incentives to work, productivity, savings and investment. As stressed by the supply-side economics theories, society gets less tools and means to be able to produce larger quantities of goods and services. The belief in the multiplier effect of public expenditure on economic growth represents an additional error. Therefore, it is necessary to reduce and reform the tax system by implementing a flat tax, combined as the supply-side economics theories, but also reduce both the weight of the state in the economy, by directing it to its traditional functions

\footnotetext{
${ }^{43}$ The Ireland went from a poor agricultural economy to a rich and technologically advanced country due to reduced rates of taxation policy, for which she earned the designation of Celtic tiger.

${ }^{44}$ Catarino (2008) 605.

${ }^{45}$ Bragues (2012) 11. Trans. [in an attempt to advance the social democratic project, or, as it is called in Portugal, the welfare state, the focus has been to build a state apparatus that ensures positive rights].

${ }^{46}$ Mises (2012).
} 
(pre-welfare state, defence, internal affairs, justice, construction of infrastructures), and its level of social intervention.

It must also be concluded that democracy has accentuated the power of interest groups that, in the orbit of political parties, seek to pass the costs of their privileges to other taxpayers, which has led to players with less power of influence in the democratic process to take the weight of their payment, i.e. with the highest tax burden, when the constitutional goal seems to indicate otherwise.

In short, we defend the implementation of the supply side economics theories in order to obtain a number of positive effects on economic growth: increased rates of profitability by reducing tax rates, encouraging savings and investment by the reduction of interest rates; the reduction of tax rates on the companies' actual return, which promotes investment through increased return on invested capital; the increase of savings, which lead to greater liquidity and lower demand for credit, thus contributing to the reduction of interest rates, which in turn encourage capital spending and domestic investment; the increase of the ratio investment vs. Gross National Product, which reveals higher productivity and allows the production of a greater number of goods and services by unit, not increasing unit costs so quickly; the increase in labour supply, stock of capital and productivity, resulting in the growth of the productive capacity of the economy and its international competitiveness; the reduction of inflationary pressure caused by insufficient supply, given increased productive capacity; the increase in internal and external demand of goods and services produced, provided by low levels of inflation, strengthening the productive capacity of the economy; the attraction of foreign capital; and the increase in real disposable income, with the consequent increase of the employment rate and consumption.

This theory should have an underlying flat tax that shows the following characteristics: a linear tax rate that preferably does not exceed $20 \%$, applicable to all income above a certain level of income (below this level there will be no taxation); a reduced tax burden on the income of natural and legal persons, in which the rate will be identical; the elimination of deductions, exemptions, rebates, exceptions and special arrangements and the creation of a single exemption applicable to the household; non-taxation of interest, dividends and capital profits received by individuals by being subject to corporate income tax; taxable income subject to tax only once; neutrality of tax revenues, so that there is economic neutrality and decreased tax evasion; better distribution of the tax burden by increasing taxes on taxpayers with greater financial capability, achieved by the end of incentive schemes, benefits and deductions; a moderate rate, greater efficiency, fairness, equity and simplicity, reducing administrative costs of tax administration and compliance by the taxpayer. Eventually, the tax system should adhere to a general system on income consumed, in which the taxpayer is taxed by what he takes out from the economy, through the adoption of the principle of consumption.

In light of the foregoing, it must be concluded that the current tax system is unsustainable, and its change is inevitable. The answer to the question of this 
work on the fairness and equity of taxation according to the flat tax, must, first of all, be concluded by the deficiency of the current redistributive system. First, there is a problem of conceptualization and definition of the concept of social justice and its effective results. Then, there are structural problems resulting from legal uncertainty promoted by constant legislative changes without practical results.

From the analysis of the actual results of the current redistributive system it can be seen that the goal of reducing inequalities has not been achieved. Furthermore, the economic and financial costs far outweigh the benefits that could be achieved. These costs are now very costly to society and stem from the high complexity of the tax system and the high level of tax burden, which is assumed as a true confiscation. In addition, equity and redistribution through the use of increasing marginal rates, along the lines in which they were constitutionally envisaged, has become a dogma.

This dogma is based on the objective of redistribution, in obtaining financial resources to the state and in a public policy of decreasing the wealth of the most powerful contributors, but as demonstrated these objectives have not been achieved. Evidence shows that increasing the tax burden on the richest classes has not had the desired effect of increasing the income of other taxpayers. In fact, the effects have been exactly the opposite of the desired ones.

The focus should be on the economic growth, which will even allow higher social gains than the currently obtained, avoiding the negative effects that were proven to exist on the employment, wealth, savings, productivity and investment. In effect, the high rising marginal rates hinder economic development, savings and investment. It is in this way that the decline in employment and income is reached. So, this tax system must itself be considered unfair and unequal.

On the other hand, the flat tax presents itself as a fairer and more equitable tax system on redistribution, removing the political redistribution and, additionally, it is more efficient from an economic point of view.

In conclusion, the solution goes through the drastic simplification of tax rules and accessory duties in order to reduce administrative and compliance costs, which facilitates the proper supervision by taxpayers on the effective application of justice. This way, the tax system becomes more transparent, allowing taxpayers to understand how they are being taxed and, thus, verify compliance with the principle of equality.

This measure is consolidated in a single marginal tax rate (linear), the designated flat tax, which would apply the same rate to all income that reached certain levels, since below would be exempt. This way there would be no disincentive to enrichment, it would encourage investment, savings, economic initiative, productivity and economic growth. However, this is not a pure proportional tax (constant marginal rate) for predicting progressivity in lower incomes. In addition, this solution requires the elimination of all personal or family expenses, except for the exemption (deduction) that would be created for all households. 
The above conclusion means abandoning the idea of horizontal equality, but reduces administrative and compliance costs; broadening the tax base, because the ways to restrict or eliminate the incidence of tax are reduced; using more expeditious ways of charging the tax through withholding, relieving the cooperation duties of the taxpayer. In effect, widening the tax base and reducing the administrative costs would make it possible to maintain the level of tax revenues, despite the tax relief.

The flat tax would make it unnecessary to separate taxation of legal persons, which would avoid the phenomenon of economic double taxation of dividends distributed. This thought also puts in question the very vertical equality, but as evidenced, it is questionable today whether the current progressive tax system is able to do better. Moreover, the complexity undermines any notion of justice and equality, casting serious doubts on «se a igualdade pelo imposto encontra pleno fundamento ${ }^{47}$.

The flat tax proposal responds both to the demand of efficiency and justice. In fact, it will be impossible to please all the classes and socioeconomic groups, since the interests that hide behind the complexity of regulations, administrative costs, and bureaucracy are very powerful, because certain groups live of the exploitation of complexity, lobbying for exception schemes.

Finally, the submitted proposal is not without $\operatorname{costs}^{48}$, especially in the transitional period until the full adoption of the flat tax, but which reform does not have transition costs for the modification of the economic expectations framework? In the absence of a good tax system, the flat tax is a good solution for the necessary tax reform, being a great solution in an imperfect world.

\section{References}

Adam, S. \& Browne, J. (2006, Agosto). Options for a UK â€ TM flat tax': Some simple simulations. Institute for Fiscal Studies (IFS). Retrieved from de http://www.ifs. org.uk/bns/bn72.pdf

Araújo, F. (2004). Introdução à Economia (2. a ed., Vol. II). Coimbra: Almedina.

Bragues, G. (2012). A Crise de Portugal - Papel da Social-Democracia. Gabinete de Estudos Gonçalo Begonha. Retrieved from de https://issuu.com/gegb/docs/acrise deportugal

Brook, A.-M., \& Leibfritz, W. (2005, Outubro). Slovakia's Introdution of a Flat Tax as Part of Wider Economic Reforms. Organisation for Economic Co-operation and Development. Retrieved from de http://www.oecd.org/officialdocuments/ publicdisplaydocumentpdf $/$ ?doclanguage $=$ en $\&$ cote $=\mathrm{ECO} / \mathrm{WKP} \% 282005 \% 2935$

\footnotetext{
${ }^{47}$ Catarino (2008) 605. Trans. [whether there are full grounds to find equality through taxes].

${ }^{48}$ See Hall \& Rabushka (1985) and Hall \& Rabusjka (1995) who recognise that the flat tax in the long run benefit the lower income citizens, but at the expense of some disincentive on productivity and, therefore, would promote a slowdown of growth rates and the penalty of the older generations.
} 
Browning, E. K. \& Browning, J. M. (1985). Why not a True Flat Rate Tax? Cato Journal, 5(2), 629-650.

Cabré, J. M. D. (2000). The Flat Tax: Theoretical Study and Empirical Analysis of the Redistributive Effect in Spain. VII Encuentro de Economía Pública: hacienda pública y recursos humanos. Retrieved from de https://dialnet.unirioja.es/serv let/articulo?codigo $=3141453$

Catarino, J. R. (2008). Redistribuição Tributária, Estado Social e Escolha Individual. Coimbra: Almedina.

Catarino, J. R. \& Guimarães, V. B. (2012). Lições de Fiscalidade (1. ${ }^{a}$ ed.). Coimbra: Almedina.

Caterbery, E. R., Cook, E. W., \& Schmitt, B. A. (1985). The Flat Tax, Negative Tax, and VAT: Gaining Progressivity and Revenue. Cato Journal, 5(2), 521-536.

Cook, E. W. (1985). Revenue and Distributional Impacts of the Hall-Rabushka Flat Tax Proposal, 5(2), 477-480.

Cruz, J. N. (2008). Economia e Política: Uma Abordagem Dialéctica da Escolha Pública. Coimbra: Coimbra Editora.

Egger, J. B. (1985). The FLANVAT as Tax Reform. Cato Journal, 5(2), 537-542.

Ferreira, E. P. (2004). Ensinar Finanças Públicas numa Faculdade de Direito. Coimbra: Almedina.

Forbes, S. (2005). Flat Tax Revolution, using a postcard to abolish the IRS. Washington DC: Regnery Publishing Company.

Franco, A. L. de S. (1995). Finanças Públicas e Direito Financeiro (4. ${ }^{\mathrm{a}}$ ed., Vol. II). Coimbra: Almedina.

Friedman, M. (2002). Capitalism and Freedom. Chicago: University of Chicago Press. Friedman, M., \& Friedman, R. (2012). Liberdade Para Escolher. Alfragide: Lua de Papel.

Grecu, A. (2004). Flat Tax - The British Case. Adam Smith Institute. Retrieved from de http://adamsmith.org/sites/default/files/images/uploads/publications/flattax.pdf

Gwartney, J. D. \& Long, J. (1985). Is the flat tax a radical idea? Cato Journal, 5(2), 407-432.

Hall, R., \& Rabushka, A. (1985). The Route to a Progressive Flat Tax. Cato Journal, $5(2), 465-476$.

Hall, R., \& Rabushka, A. (1995). The Flat Tax (2. ${ }^{\text {a }}$ ed.). Stanford: Hoover Institutution Press.

Hayek, F. A. (1992). Law, Legislation and Liberty, The Mirage of Social Justice (Vol. 2). Chicago: University of Chicago Press.

Hayek, F. A. (2013). Law, Lesgislation and Liberty: a New Statement of the Liberal Principles of Justice and Political Economy. London: Routledge.

Keen, M., Ivanova, A., \& Klemm, A. (2005). The Russian Flat Tax Reform (IMF Paper Working No. WP/05/16) (p. 48). International Monetary Fund. Retrieved from de https://www.imf.org/external/pubs/ft/wp/2005/wp0516.pdf

Keen, M., Kim, Y., \& Varsano, R. (2006). The «Flat Tax(es)»: Principles and Evidence (IMF Paper Working No. WP/06/218). International Monetary Fund. Retrieved from de https://www.imf.org/external/pubs/ft/wp/2006/wp06218.pdf

Lee, D. R. (1985). Are politicians interested in honest tax reform? Cato Journal, 5(2), 433-436.

Minarik, J. J. (1985). Semantics of the Flat Rate Tax and Tax Reform. Cato Journal, 5(2), 437-448. 
Mises, L. von. (2012). Socialism: An Economic and Sociological Analysis. United States of America: Important Books.

Moore, D. (2005). Slovakia's 2004 Tax and Wefare Reforms (IMF Paper Working No. WP/05/133). International Monetary Fund. Retrieved from de https://www.imf. org/external/pubs/ft/wp/2005/wp05133.pdf

Musgrave, R. A. \& Musgrave, P. B. (1989). Public Finance in Theory and Pratice (5. ${ }^{\text {a }}$ ed.). Singapore: International Edition.

Nabais, J. C. (2015a). Estudos de Direito Fiscal - Por um Estado Fiscal Suportável (Vol. 2. ${ }^{\circ}$ ). Coimbra: Almedina.

Nabais, J. C. (2015b). O Dever Fundamental de Pagar Impostos - Contributo para a compreensão constitucional do estado fiscal contemporâneo (4. ${ }^{\text {a }}$ ed.). Coimbra: Almedina.

Paulus, A., Cok, M., Figari, F., Hegedüs, P., Kump, N., Lelkes, O. \& Võrk, A. (2009). The Effects of Taxes and Benefits on Income Distribution in the enlarged EU (Working Paper No. EM8/09). EUROMOD. Retrieved from de https://www.iser. essex.ac.uk/research/publications/working-papers/euromod/em8-09.pdf

Peichl, A. (2006). The Distributional Effects of a Flat Tax Reform in Germany - A Microsimulation Analysis. Retrieved from de https://www.researchgate.net/ publication/228705889_The_Distributional_Effects_of_a_Flat_Tax_Reform_in_ Germany-A_Microsimulation_Analysis

Peichl, A. \& Paulus, A. (2009). Inequality neutral flat tax reforms in Europe: differences between East and West. Retrieved from de http://www.ecineq.org/ ecineq_ba/papers/Peichl2.pdf

Peterson, P. P. (1985). Lingering Questions about Tax Reform. Cato Journal, 5(2), 651-656.

Randjelovic, S. \& Zarkovic-Rakic, J. (2010). Distributional and Poverty Effects of Income Tax Reform in Serbia. Faculty of Economics and Foundation for the Advancement of Economics (FREN), University of Belgrade. Retrieved from de http://siteresources.worldbank.org/INTECAREGTOPPOVRED/Resources/SasaR ANDJELOVIC.pdf

Stiglitz, J. E. (2000). Economics of the Public Sector (3. ${ }^{a}$ ed.). United States of America.

Stroup, R. L. (1985). The Progressive Rate - Progressive Revenue Myth. Cato Journal, 5(2), 449-453.

Teather, R. (2005). A Flat Tax for the UK - a Practical Reality. Adam Smith Institute. Retrieved from de http://www.adamsmith.org/sites/default/files/images/uploads/ publications/flattaxuk.pdf

Teixeira, G. (2010). Manual de Direito Fiscal (2. ${ }^{\text {a }}$ ed.). Coimbra: Almedina.

Voinea, L. \& Mihaescu, F. (2009). The Impact of the Flat Tax Reform on Inequality The Case of Romania. The wiiw Balkan Observatory. Retrieved from de http:// wiiw.ac.at/the-impact-of-the-flat-tax-reform-on-inequality-the-case-of-romaniadlp-3217.pdf 
